\title{
Alzheimer's Disease and the Immune System
}

\author{
Kyle Sutherland ${ }^{1,2}$, Tianchen $\mathrm{Li}^{2}$ and Chuanhai Cao ${ }^{1,2,3 *}$ \\ ${ }^{1}$ Department of Pharmaceutical Science, College of Pharmacy, University of South Florida, Tampa, FL 33612, USA \\ ${ }^{2}$ USF-Health Byrd Alzheimer's Institute University of South Florida, Tampa, FL 33613, USA, 3Department of Cell Biology, Microbiology and Molecular \\ Biology, University of South Florida, Tampa FL 33620
}

\begin{abstract}
Received: October 02, 2014; Accepted: January 05, 2015; Published: January 22, 2015
*Corresponding author: Chuanhai Cao Ph.D, Department of Pharmaceutical Science, College of Pharmacy, University of South Florida, Tampa, FL 33612, USA, USF-Health Byrd Alzheimer's Institute University of South Florida, Tampa, FL 33613, USA; Department of Cell Biology, Microbiology and Molecular Biology, University of South Florida, Tampa FL 33620, USA, E-mail: ccao@health.usf.edu
\end{abstract}

\begin{abstract}
Alzheimer's disease (AD) has been known for over 100 years, but has only just become a pressing matter at the end of the 21st century. $\mathrm{AD}$ is a disease related to the aging of the individual, and has its burden over the population has continued to increase as medicine and technology are continuing to lengthen the lives of individuals. Changes in the body associated with aging, such as a weaker immune system, are causing the buildup of the protein associated with $A D$, amyloid beta $(\mathrm{A} \beta)$. Although the monomer forms of this peptide are a normal occurrence within the body, the oligomer or higher multiunit forms of the peptide present problems to the neurons and local environment in the CNS. The molecules become toxic to the area, and they are flagged by the body to be cleared. Antibody production, opsonization, and phagocytosis by astrocytes and microglia cells in the brain have been shown to help clear this burden. However, this clearing process also can trigger pro-inflammatory pathways and secrete inflammatory cytokines, and this inflammatory response goes on to further promote the pathological changes associated with $\mathrm{AD}$. One of the major progressors of $\mathrm{AD}$ is the dysfunction of the immune system caused by abnormal peptide folding in the CNS. Although the immune system of aged patients tend to be fragile with respect to function, acting through immune modulation and immunotherapy are currently seen to be some of the most beneficial techniques for age related diseases. In this review, we will discuss the relation of $\mathrm{AD}$ to age and the immune system, and then introduce the current options and treatments regarding immune modulation and immunotherapy.
\end{abstract}

Keywords: Alzheimer's disease; Neuroimmunology; Immune modulation; Immune therapy; Beta amyloid; Immunotherapy

\section{Introduction}

Aging and inflammation are a couple of the greatest factors and contributors to disease. When examining the top ten causes of disease-related death in the United States, a handful of those are progressed through low levels of chronic inflammation in the senior patients.

Inflammation is a factor in heart disease, stroke, cancer, respiratory disease, diabetes and Alzheimer's disease (AD) [16]. This level of chronic inflammation may be a result of cellular or mitochondrial dysfunction [7]. As the levels of inflammation, both acute and chronic, increase with the level of free radical production in the cell, which may in turn affect the function of the mitochondria. These effects of aging in turn increase inflammation in the body, which may also affect the progression of a person's disease state.

$\mathrm{AD}$ is a plight upon the elderly which trickles down to burden the rest of society. It is quickly becoming one of the most economically taxing diseases to developed countries $[8,9]$. It currently stands as the $6^{\text {th }}$ deadliest of diseases facing the US, and is continuing to rise without any substantial advances in treatment [10]. Of the 45 million aged persons living in the US, approximately 5 million of that number have been diagnosed with Alzheimer's [10]. This equates to 1 out of every 9 of the elderly population suffering from this disease. The Alzheimer's Foundation of America reports that the life expectancy for these individuals is generally anywhere from 8-10 years, with fewer than 3 percent of people living past 14 years post-diagnoses $[11,12]$. This timeline, however, is variable from person to person, and depends on the patient's age and overall health at the time of diagnoses. Some major factors of a person's survivability are their overall health and level of inflammation throughout their disease progression.

This review article will discuss the points of Alzheimer's and inflammation, and will talk about possible immune therapies to treat the inflammation causing the progression of AD.

\section{Alzheimer's Diseases an Age Related Disease}

Alois Alzheimer was the first to describe the hallmark pathologies within the brain of a demented patient in 1906, and these pathologies were later named after the psychiatrist who first described them, as Alzheimer's disease (AD). Although the history of this disease is more than 100 years, it has not been considered as major health issue until this century. It has developed into a problem for many nations. Although people are living longer lives, there is a larger population of elderly at risk for developing the disease. The patient population is increasing rapidly, and because of this so is the financial burden.

$\mathrm{AD}$ is an aging related disease. The cases which are associated 
with earlier onset, which occur between the ages of 30-60, only makeup $5 \%$ of cases [13]; earlier onset can be caused by familial inheritance Alzheimer's (FAD) or by unknown causes. The cases caused by FAD are of autosomal dominant inheritance, and only represent $0.1 \%$ of total $\mathrm{AD}$ cases [14]. The genes affected in this case are related to the amyloid precursor protein (APP) gene on chromosome 21, and it is these mutations in APP that many of the therapeutic animal models are based on [15]. All other cases of Alzheimer's are referred to as sporadic AD, which make up 95\% of the total disease cases, and it is seen generally in people over the age of 65. It is suspected that genetic and environmental risk factors play roles in the pathology.

In terms of testing for the genetic risk factors for late-onset $\mathrm{AD}$, as of now there is that of the allele $\varepsilon 4$ of the apolipoprotein (APOE) gene [16]. A variant in the gene can be found in $40-80 \%$ of all Alzheimer's cases [17]. For earlier-onset, there are various mutations, with most of them residing in the APP, Presenilin 1 (PSEN1; on chromosome 14), or Presenilin 2 (PSEN2; on chromosome 1) genes. Although testing for the APOE allele is available, it is not a determinant of whether you will or will not get AD, but merely increases a person's risk of ever developing $\mathrm{AD}$ if the abnormal allele is present.

As of now, there are no reliable prognoses for $\mathrm{AD}$, and a patient won't know if they will ever contract the disease until they are experiencing the signs and symptoms. However, the signs between normal aging, $\mathrm{AD}$, and dementia also have a lot of overlap. It is difficult to quickly discern one from the other. Getting old has its own features on the body, and tampering with retaining information and short term memory are among them $[18,19]$. However, when this progresses to a degree where the forgetting becomes more constant, and it gets to a degree where the patient doesn't even recognize that they are no longer retaining information, it starts to interfere with the patient's daily life. These are the early stages of dementia. According to the Alzheimer's Association, AD makes up about $60-80 \%$ of all cases of dementia. The two overlap until it can be difficult to pull out the diagnoses of AD from dementia. A full medical workup will be required to discern one from the other. No matter what factors have been uncovered, the biggest of all the risks is aging.

\section{The Immune System Declines with Age}

In addition to memory and the brain, the immune system also declines with age. This has been identified physically in the shrinkage of the thymus, in the loss of functionality of the appendix, and in the increasing instances of disease and infection in the elderly subjects. Older individuals also have a weaker response to vaccination compared to younger individuals [20]. This is caused by an inability to maintain the level of homeostasis previously preserved throughout earlier life. This too presents economic problems to the nation, as the group of people over the age of 65 is quickly growing and it is this group requiring more of the medical attention and funding. Their growing numbers are due, in part, to the fact that people are living longer with medical advances, and that the baby boomer generation is becoming of retirement age. This group will swell over the next 10 years, and will present a challenge to the current medical structure [21].
The immune system of our body can be classified into native, or innate, and adaptive systems. The innate immune system acts as natural defense, whereas the adaptive system requires priming and training to in order to act against specific antigens.

There are studies stating that most of the innate immunity is preserved throughout the aging process [22]. One of the more interesting cell population to decline with age, and is part of the innate immunity, is that of dendritic cells (DC) [23]. These cells are the messengers between the innate and adaptive immune responses by presenting antigens to $\mathrm{T}$ cells, and thereby activate the adaptive immune system. Although the DC's function seems to be maintained throughout life [24-26], there is a drop in physical cell numbers. There are less antigens being presented to help $\mathrm{T}$ cells activity, simply because the body doesn't have the numbers. Due to this fact, aged subjects are more acceptable to pathogens that they once had protection from.

Changes in the adaptive immune system, such as those to B and $\mathrm{T}$ cells, also hinder our ability to maintain a healthy body in advanced age. The two most important aspects of the adaptive immune system are the 1) ability to have a massive repertoire of specific and diverse antigen-recognizing populations, or naïve lymphocytes, and 2) the ability to maintain populations of cells that have already encountered antigens months or years prior, and still have the ability to fight said antigens. As the aging the process occurs, there is a notable decrease in the size of the thymus, which results in an overall decrease in the size of the naïve T lymphocyte population [27] and the loss of hematopoietic bone marrow causes a loss in naïve B cells [28]. Without a large population of naïve cells at later ages, the population of memory cells, formed against pathogens at earlier ages, begin to go through oligoclonal expansion with reduced antigen recognition [29]. These alterations result in changes to the normal levels of gene expression and to the amount of cytokines and signaling molecules released [30]. The system becomes more dependent on what defense has already been made and almost abandons the shrinking population of naïve cells, and as a result the body becomes more susceptible to new pathogens.

In patients with $\mathrm{AD}$, the usage of the innate immunity can be seen in the aspects of phagocytosis and inflammation in the CNS. The microglial and astrocyte cells have some phagocytic ability in clearing the burden of the amyloid beta $(A \beta)$ peptides, those aggregated forms thought to cause AD, from the CNS [31]. Thus, with the activation of the innate immune system comes widespread inflammation throughout the CNS. Inflammation can be seen by testing for various cytokines and chemokines on the brain in post-mortem subjects with $\mathrm{AD}$ pathologies $[32,33]$. However even when there is infection outside of the CNS, and this is especially common in the elderly, there is activation of the peripheral immune system and secretion of inflammatory factors. The cytokines produced peripherally are carried to the brain via the circulatory system, where the effects of these cytokines are reciprocated in the CNS [34]. This can increase inflammation in the brain, and lead to signs of depression and can exacerbate CNS disease. 
The adaptive immunity also plays a role in the clearance of the $A \beta$ deposits, and this can be enhanced through the immunization at a peripheral location with exogenous $A \beta$ in mice $[35,36]$. However, it is unclear whether this works as well endogenously in the body, but it was found that $\mathrm{T}$ cells may have some intrinsic reactivity to the $A \beta$ peptide, and that this reactivity may be increased with the increasing age of the subject [37]. When $A \beta$ activated $T$ cells were transferred into APP/PS1 transgenic mice, the mice can improve significantly in their behavior performance $[38,39]$. Some of the B cell and T cell epitopes of the $A \beta$ peptide have also been elucidated $[40,41]$, which provide evidence that the peptides may trigger responses normally in the body. When the $A \beta$ vaccination trial moved onto human subjects, it was suspended due to some patients suffering from meningoencephalitis $[42,43]$. This side effect was suspected to be the cause of over activation of the immune system, thereby inducing inflammation. Many think this was caused by the adjuvant used to prime the immune system for the delivery of the $A \beta$ peptide [44-47]. Since $A \beta$ vaccination has been proven to prevent disease progression $[48,49]$, other methods of delivery have been worked on in recent years. The initial end-goal ideas of the $A \beta$ vaccine has remained the same, but the components of how to accomplish the end-goal have been altered, such as the method of vaccination (intranasal, intramuscular, subcutaneous, etc.) and what components to include in the vaccine $(A \beta$ only, $A \beta+$ adjuvant, other compounds to help initiate an immune response, etc.). It was found that anti-inflammatory cytokines, such as IL4, IL10, and TGF $\beta$, could be seen when $A \beta$ was administered intranasally [37]. It is through this intrinsic activity of $\mathrm{T}$ cells that we can activate components of the immune system, without activating the mass pro-inflammatory cytokine reaction that causes widespread side-effect pathologies in the CNS.

Another large aspect of aging individuals is a low-level of chronic inflammation persistent in the body. This can be associated with an increase in free radical oxygen species or a decrease in cellular and mitochondrial function, or both. It has been long thought that oxidative stress plays a great factor in $\mathrm{AD}$ $[50,51]$. In the AD brain, there seems to be a higher concentration of iron $(\mathrm{Fe})$ and copper $(\mathrm{Cu})$ which can cause production of more free oxygen radicals to be produced by Fenton reactions, as well as increased levels of protein and DNA oxidation [52]. It is also thought that the neuronal membranes, and their oxidation by these free radicals, may be responsible for the conversion of monomeric $A \beta$ into $A \beta$ plaques and fibrils [53]. However free radicals and oxidative stress produce their effects, they are still believed to be a key factor in the progression of the disease $[54,55]$.

\section{Aggregated Amyloid Beta Presents a Problem to the Immune System}

Although the function of amyloid beta $(A \beta)$, a peptide made up of 42/43 amino acids, is not well understood [56], they are an endogenous component in the brain. This molecule is constituted to extracellular plaques, one of the hallmark in AD. The other trademark of the disease that Alois Alzheimer elucidated was the tau protein, or neurofibrillary tangles (NFTs) inside the neuronal cells. Although the NFTs play some major role in AD, it is questionable how big that role actually is, as they are seen in many other neurodegenerative disorders [57-60]. For example, the transgenic mouse model of the disease, showing the amyloid cascade, does not exhibit the tau pathologies $[15,61]$. Studies have focused on changing the external amyloid plaques rather than changing the internal makeup of the cell to alter NFTs. In respect to $A \beta$, how is it that a peptide normally residing in the body throughout life can suddenly cause the pathologies of AD, and ultimately the deterioration of the brain? It comes from the combination of declining homeostasis, the decline in immune function, and the ability of the $A \beta$ peptides to become larger plaques.

The A 342 peptide is highly hydrophobic and sticky. It normally resides as a part of the amyloid precursor (APP) protein in the membranes of neurons, which are concentrated at the synapses. It is cleaved by 2 secretase enzymes (beta, and gamma) from APP, and when cleaved produces two isoforms $-\mathrm{A} \beta_{40}$ and $A \beta_{42}$. The $A \beta_{40}$ isoform is the most common in the body, but the $A \beta_{42}$ is the more likely of the two to form oligomers and fibrils, which result in the amyloid plaques. Cleaved $A \beta$ monomers are normally degraded by amyloid-degrading enzymes, such as neprilysin [62]. When two or more of these cleaved $A \beta$ proteins come together, they form misfolded oligomers. These soluble oligomers have been shown to be synaptotoxic [63], and also serve as "seeds" that will eventually grow into bigger polymers of $A \beta$, which are the amyloid plaques found in the synapses [64]. When $A \beta$ self-aggregates, it generates many isoforms that are harmful to the local neurons. It creates radical oxygen species [65], which in turn tend to cause lipid peroxidation of the neuronal membranes and cause the formation of reactive aldehydes [66]. These aldehydes go on to cause problems with ATPases, glucose and glutamate transporters, and eventually cause depolarization of the neuron. When the neuron depolarizes, it causes complications with neuron signaling and excitability, calcium influx, and mitochondrial function [67].

The immune system recognizes $A \beta$ monomers as normal, so no immune response is mounted against it. However, oligomers and larger polymers are difficult to metabolize and clear. The different isoforms can confuse the immune system, and are seen as foreign to the body. This causes the activation of cells and mass inflammation to occur in the brain. The $A \beta$ oligomers, seen as foreign molecular structures, activate the innate immune system through pattern recognition receptors (PRR). This inflammatory process goes on to cause the AD pathologies [68]. The idea of this malicious cycle of $A \beta$ production and chronic inflammation is summed up in Figure 1. These additive structures of $A \beta$ are recognized by microglial and astroglial cells in the CNS through the PRRs. The microglial cells are then able to phagocytize the $A \beta$ [69] and store the peptide inside the cell, reducing the burden of building plaques, but it is unsure if the microglial cells have the capability to degrade all the isoforms of $A \beta$. In a study performed by Wyss-Coray, exogenous astrocytes could degrade $A \beta$ without additional stimuli, whereas microglial required stimuli from various cytokines or opsonizing antibodies [70,71]. Even with 


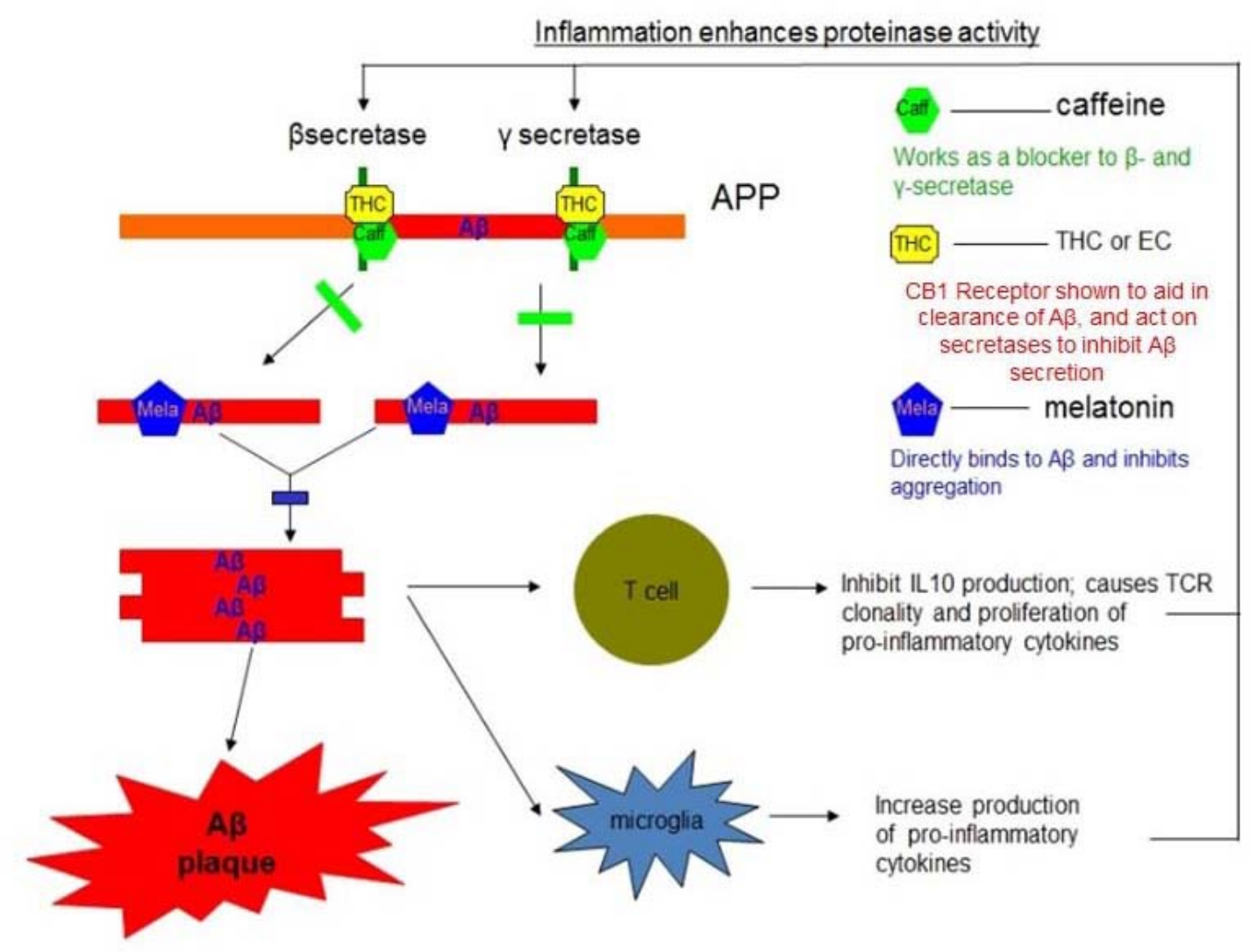

Figure 1: The animation shows the inflammatory cycle that takes place in the brain of patients with Alzheimer's disease. When the individual ages, there is the dampening of metabolism and clearance of $A \beta$ peptide in the brain. These $A \beta$ monomers, normally cleared from the body, may aggregate into oligomers, which then are seen as foreign and are phagocytized by astrocytes or microglial cells in the CNS [93]. These cells cause activation of the $\mathrm{T}$ cells, which both then go on to cause the release of pro-inflammatory cytokines [94]. There is a change in the T cell clonality of $\mathrm{AD}$, and it seems to shift towards a CD4 response over a CD8 response [95]. As IL10 is inhibited in this process, the immune system is no longer suppressed and the CD4 inflammatory response is allowed to overtake the process. Lymphocytes from the T helper cell line (such as Th1, Th2, Th9, and Th17) are important in starting and maintaining inflammatory processes. Inflammatory cytokines such as IFN-gamma, TNF, IL-2, IL-4, IL-5, and IL-13 are responsible for these effects. The level of inflammation is increased in the CNS, and this is thought to increase the activity of the secretase enzymes [96-98]. If the A $\beta$ oligomers are not cleared in time, they may aggregate further to form the amyloid plaques, which are the cause of toxicity to the neurons and local environment. These plaques are too big to be taken up by any of the antigen presenting cells (APC), and they will eventually cause the apoptosis of the nearby neuronal cells. Some molecules, such as melatonin [99], caffeine [100], and THC [101,102], have been shown to bind and alter either the secretases enzymes or the $A \beta$ molecules themselves, thereby preventing aggregation.

these ongoing attempts to clear the $A \beta$, it is thought that the peptides aggregate while being moved around from cell to cell, or even within the cell itself, and that this aggregation during handling in turn causes neuronal toxicity and cell death [72]. The binding of $A \beta$ oligomers and fibrils to other proteins within the environment, such as those containing sialic acid, can also cause the fibrils to be hidden or masked from the immune system [73]. Thus increasing the buildup of these components in the body without the immune system to recognize them. The chronic inflammation, caused by negative feedback through these PRRs, can dampen the sensitivity of glial cells to antigens, and induce immune tolerance of the $A \beta$ peptide. This could in turn exacerbate and further progress the AD pathology.

Limiting the cytokines that produce the inflammatory response can help alleviate the pathologies of AD. The development of small peptides promoting anti-inflammatory response, through the suppression of inflammatory cytokines, have been seen to be beneficial in immunomodulation [74]. Compounds, such as melatonin [75,76], caffeine [77-79] and THC [80], have been shown to prevent the aggregation of the $\mathrm{A} \beta$ peptides, and some have been shown to behaviorally benefit in the transgenic mouse model. It is worth mentioning that they are all have the ability to modulate the immune system. This also implies that activation to immune system may cause improvement in the symptoms, pathologies, and cognitive impairment of the individual.The Current Status and Future of $\mathrm{AD}$, and Immunotherapy as a Solution

In the US National Institute of Health database, there are 
Table 1: Summary of potential immune targets in AD.

\begin{tabular}{|c|c|c|}
\hline & Immune System Role & How affects disease state \\
\hline IFN- $\gamma$ & $\begin{array}{l}\text { Activator of macrophages-pro- } \\
\text { inflammatory; irregular expression } \\
\text { associated with autoimmune disease }\end{array}$ & $\begin{array}{l}\text { Activates microglia and cellular response in brain, } \\
\text { increase inflammation, A } \beta \text { plaque burden in AD } \\
\text { brain }[103,104]\end{array}$ \\
\hline TNF- $\alpha$ & $\begin{array}{l}\text { Induces inflammation and apoptotic cell } \\
\text { death; produced mainly by activated } \\
\text { macrophages }\end{array}$ & $\begin{array}{l}\text { Levels elevated in AD [105]; Inhibition of TNF- } \alpha \\
\text { may aid in treatment [106] }\end{array}$ \\
\hline IL-1 & $\begin{array}{l}\text { Increases movement of lymphocytes to } \\
\text { site of infection }\end{array}$ & $\begin{array}{l}\text { Aids progression of disease [107]; Receptor } \\
\text { antagonist shows disease improvement [108] }\end{array}$ \\
\hline IL-4 & $\begin{array}{l}\text { Induce differentiation of naïve T helper } \\
\text { cells to Th2 cells; Stimulate active B cells/ } \\
\text { humoral response }\end{array}$ & $\begin{array}{l}\text { Promote M2 cell formation, reduction of } \\
\text { pathological inflammation; Upregulated in } \\
\text { patients treated with AchE inhibitors [109] }\end{array}$ \\
\hline IL-6 & Pro-inflammatory cytokine & $\begin{array}{l}\text { Cortical senile plaques display strong IL6 } \\
\text { immunoreactivity; May be responsible for acute- } \\
\text { phase state in AD [110] }\end{array}$ \\
\hline IL-10 & $\begin{array}{l}\text { Anti-Inflammatory Cytokine; Down } \\
\text { regulate cellular response, upregulate } \\
\text { humoral response }\end{array}$ & $\begin{array}{l}\text { Strong regulator of inflammation state [111]; } \\
\text { polymorphism in IL10 promoter is a risk factor for } \\
\text { AD [112] }\end{array}$ \\
\hline IL-12 & $\begin{array}{l}\text { Induce differentiation of naïve T cells to } \\
\text { Th1 cells; helps produce IFN- } \gamma \text { and TNF- } \alpha\end{array}$ & $\begin{array}{l}\text { Inhibition of IL12 signaling reduces AD } \\
\text { pathologies and cognitive decline [113] }\end{array}$ \\
\hline G-CSF (granulocyte colony stimulating factor) & $\begin{array}{l}\text { Increase production of granulocytes and } \\
\text { granulocyte-producing stem cells }\end{array}$ & $\begin{array}{l}\text { May be reduced in early AD patients [114]; G-CSF } \\
\text { treatment rescues memory impairment in mice } \\
{[115]}\end{array}$ \\
\hline Dendritic Cells (DCs) & $\begin{array}{l}\text { Major antigen presenting cell to the body; } \\
\text { Involved in innate immune response }\end{array}$ & $\begin{array}{l}\text { Lack of DCs increases } A \beta \text { plaque in mice [116]; } \\
\text { Possible vaccination route against } A \beta[117]\end{array}$ \\
\hline
\end{tabular}

Table represents possible immune targets in $\mathrm{AD}$, their role in the immune system, and their disease implications.

Table 2: Summary of currently available therapies, approved and experimental.

\begin{tabular}{|c|c|c|c|}
\hline Therapy & $\begin{array}{l}\text { Approved vs. } \\
\text { Experimental }\end{array}$ & AD Target & Clinical Findings \\
\hline $\begin{array}{l}\text { Cholinesterase Inhibitors (Donepezil, } \\
\text { Galantamine, Rivastigmine) }\end{array}$ & $\begin{array}{l}\text { FDA approved for various } \\
\text { stages of AD }\end{array}$ & $\begin{array}{l}\text { Prevent breakdown of acetyl } \\
\text { choline in the brain-important } \\
\text { for learning and memory }\end{array}$ & $\begin{array}{l}\text { Slows cognitive symptom } \\
\text { progression but doesn't seem to } \\
\text { slow disease progression [118] }\end{array}$ \\
\hline NMDA Receptor Antagonist (Memantine) & $\begin{array}{l}\text { FDA approved to treat } \\
\text { moderate to severe AD } \\
\text { symptoms }\end{array}$ & $\begin{array}{l}\text { Regulate glutamate activity and } \\
\text { NMDA receptor activity-lessens } \\
\text { excess glutamate and calcium into } \\
\text { neuronal cells }\end{array}$ & $\begin{array}{l}\text { Slows cognitive symptom } \\
\text { progression but doesn't seem to } \\
\text { slow disease progression [119] }\end{array}$ \\
\hline Melatonin Treatment & Experimental & $\begin{array}{l}\text { Inhibit } A \beta \text { aggregation; Seen to } \\
\text { restore mitochondria function } \\
\text { and lessen load of oxidative stress } \\
{[75,120,121]}\end{array}$ & $\begin{array}{l}\text { Greatly help sleep disorders and } \\
\text { symptoms of sundowning, and } \\
\text { to slow cognitive impairment } \\
{[122]}\end{array}$ \\
\hline Caffeine Treatment & Experimental & $\begin{array}{l}\text { Blocks } \beta \text { - and } \gamma \text { - secretases } \\
\text { forming } A \beta \text { monomers }[77,100]\end{array}$ & $\begin{array}{l}\text { Shown to help reduce cognitive } \\
\text { impairment in the mouse model } \\
{[123]}\end{array}$ \\
\hline Young Lymphocyte Infusion & Experimental & $\begin{array}{l}\text { Young blood shown to change the } \\
\text { molecular, structure, and cognitive } \\
\text { function of older mice }\end{array}$ & $\begin{array}{l}\text { Young blood seen to reverse } \\
\text { effects of aging in brain of mice } \\
{[92]}\end{array}$ \\
\hline $\begin{array}{l}\text { Free Radical Scavengers and Anti- } \\
\text { inflammatory Drugs (Vitamin E, selegeline, } \\
\text { NSAIDs, etc.) }\end{array}$ & Experimental & $\begin{array}{l}\text { Oxidative stress and free radicals } \\
\text { in the AD brain }\end{array}$ & $\begin{array}{l}\text { Some improvement in terms of } \\
A \beta \text { deposition, inflammation, } \\
\text { and symptoms }[124,125]\end{array}$ \\
\hline
\end{tabular}

Table represents possible treatments, approved and experimental, in Alzheimer's, as well as possible clinical and laboratory findings. 
over 1,000 clinical trials that are currently ongoing testing the effects of compounds on AD. As of now, there are a handful of known strategies to slow or stop the pathologies of AD through intervention with the amyloid cascade. Many of these strategies, as well as most of the drugs that have been in previous clinical trials for $\mathrm{AD}$, are based on the gamma or beta secretases in the body that deal with the creation of $A \beta$ from APP. Halting or inhibiting these enzymes would drop the load on the CNS in terms of the building $A \beta$ plaques. Many of the drugs working on these enzymes, such as Semagacestat, were discontinued in the second or third phases of clinical trials due to the low activity and low beneficial significance of the compounds. This leaves us with a remaining small pharmaceutical pool consisting of cholinesterase inhibitors and NMDA antagonists. These drugs work through altering the conditions in the brain, which overlap with the pathologies of $\mathrm{AD}$, and they usually improve the conditions in the CNS to temporarily halt the disease progression. The activity of these drugs depends on the individual, and it is only for a temporary halt to progressing past the stage of mild AD.

Another strategy currently being studied is that of antiaggregation molecules. These molecules, such as melatonin and caffeine, prevent the bunching of the $A \beta$ peptides. These compounds tend to show the improvement of mitochondrial function in the cell, and also provide some degree of neuroprotection. Melatonin has even shown to cause improvement of neurogenesis in the hippocampus [81]. Although these compounds do provide benefits, these tend to be temporary in terms of $\mathrm{AD}$ and the progression of its pathologies. Though incorporating these molecules into the individual's diet, along with sufficient stimulation and exercise, seems to be particularly effective in halting the disease [82,83].

Immunotherapy has been showing increasingly substantial results in terms of treating AD over the last 10 years. The idea has been to stimulate the host immune system to recognize and eliminate the amyloid protein plaques or oligomers without causing any other side effects. It is simple in theory, but has been shown to be increasingly difficult to carry out. Immunization has been shown to produce antibodies to the amyloid peptide and to prevent the formation of the $A \beta$ plaques. Previous vaccination with $A \beta 42$ has shown to reduce the number of plaques, but it has not halted the progression of the neurodegeneration [84]. Still, immunotherapy seems to be the way to move forward in terms of finding significant treatment or a cure.

One of the ways that immunotherapy might be helpful is by taking advantage of a process already in place. The stimulation of the systemic adaptive immune system, induced by $A \beta$, seems to be positive to the mice they have been studied in, in terms of the pathologies and behavioral changes $[48,85]$. It can be difficult, however, to prime the immune system to a specific or a couple of epitopes from $A \beta$. For example, insulin is made up of 51 amino acids, but has over 115 antibody epitopes on its surface due to all the overlapping domains of the amino acids [86]. Each epitope has approximately 15 amino acids in its sequence, where 5 of these amino acids strongly influence the binding ability of the epitope to the epitope binding site on antibody or MHC molecules. One of the great things about the adaptive immune system is that it is so specific in response to the antigens presented. It may be that finding the right domain may be the answer to the problems associated with vaccination.

However, the problem with vaccination in aged subjects is that they have a weaker response to the peptide due to the dampened, aged immune system. The antibody response to an antigen in the elderly is smaller in number and dissipates faster [20]. This process, also known as immunosenescence, is the reason adjuvants, molecules such as aluminum salts, are required. The adjuvant keeps the antigen from dispersing from the site of injection, and begins to stimulate the innate immune response. It has been thought that the CNS inflammation that occurred from earlier AD vaccination studies was due to the adjuvant used in the vaccine [44]. Other types of immunization have been studied since then, such as mucosal or intranasal inoculation. However, these treatments required repetitive treatments regimens and only partially cleared the $A \beta$ plaques $[87,88]$.

Thinking of different forms of vaccination may beneficial in terms of finding a cure, or even just to better understand the system. Harnessing the potential of a dendritic cell's (DC) ability to present antigens to the system is a possibility, and is currently being studied [89]. Taking a person's DCs, populating them, instructing them to uptake an antigen, and injecting these same cells into the person as a vaccine may be a feasible vaccination route in the future. With this process, there would be minimal chance for rejection of the vaccine, and the functionality of the DCs has been shown to be efficient throughout life, even in elderly populations. Though the amount of cells present in older individuals is less than that of their younger counterparts $[90,91]$. It could be that infusing large numbers of DCs, already having taken up an antigen, could provide substantial activation of the immune system to clear the body of said antigen, without causing the inflammation or other side effects.

In terms of a possible prognosis for $\mathrm{AD}$, instead of manipulating the immune system, it may be possible to read the changes already written in the cell population of a person's immunity. There are enormous numbers of naïve T cells in the human body, each one waiting to respond a specific antigen. When the antigen matches up with the corresponding $\mathrm{T}$ cell, the $\mathrm{T}$ cell begins to replicate, thereby forming a population of clones to track out all the copies of the same epitope. If the epitope is represented on the $\mathrm{A} \beta$ peptide, and there is activation of the $\mathrm{T}$ cells, then the clones can be detected in the peripherally in the system. The changes in the $\mathrm{T}$ cell receptor (TCR) can then be detected peripherally by exacting the patient's blood and examining the changes in TCR clonality. It may be that these changes can be detected with a level of accuracy, and that this level may represent a reliable prognosis to the changes in the body formed from AD.

The current idea for treatment is returning the immune system back to the image of what it looked like in youth. In one of the biggest clinical studies for AD, Wyss-Coray and his lab are going to infuse AD patients with young blood. In previous studies by his lab, the infusion of blood from younger mice recharged the 
brain of the older mice [92], and they are hoping to replicate this result in humans. However, it may not be the entirety of the blood that we need; it may be just one or two components that were present at one point in adolescence, but are lost or functionally lessened as we age. Either way, Alzheimer's disease is a pathology of aging, and the key to unlocking this disease may very well be found in the youth.

\section{Conclusion}

The marriage between inflammation and aging is one that is ultimately detrimental to the patient, and it is a common factor in many of the highest disease mortality rates. As the patient's age increases, so does their risk for developing dementia, and possibly AD. Something that is commonly known is that when we get older, we become more at risk of developing disease and infection, which is a result of our declining immune system. We see that our immunity is highest when we are relatively young to mid-age, and from there we are trying to maintain this level of immunity from declining. A common theme in patients with AD is a dysfunction of the immune system and higher than normal levels of inflammation. Treating both of these will help us come to a reliable therapy to treat $\mathrm{AD}$ and other similar neurological diseases.

It is our thoughts, that through immunotherapies and neuroimmune manipulations, that we can treat a wide array of disease. With these new technologies, like immune cell infusion in elderly patients, DC vaccinations, and T cell receptor monitoring, we can effectively treat the disease and the changes the make to our body's watchdogs, the immune system.

\section{References}

1. Danesh J, Whincup P, Walker M, Lennon L, Thomson A, Appleby P, et al. Low grade inflammation and coronary heart disease: prospective study and updated meta-analyses. BMJ July 22, 2000;321:10903648.

2. Jin R, Yang G, Li G. Inflammatory mechanisms in ischemic stroke: role of inflammatory cells. J Leukoc Biol May 2010;87:20130219. doi:10.1189/jlb.1109766.

3. Rakoff-Nahoum S. Why Cancer and Inflammation? Yale J Biol Med December 2006;79:17940622.

4. Tetley TD. Inflammatory cells and chronic obstructive pulmonary disease. Curr Drug Targets Inflamm Allergy December 2005;4:17305517.

5. King GL. The role of inflammatory cytokines in diabetes and its complications. J Periodontol August 2008;79:18673007. doi:10.1902/ jop.2008.080246.

6. Akiyama H, Barger S, Barnum S, Bradt B, Bauer J, Cole GM, et al. Inflammation and Alzheimer's disease. Neurobiol Aging June 2000;21:10858586.

7. Escames G, López LC, García JA, García-Corzo L, Ortiz F, AcuñaCastroviejo D. Mitochondrial DNA and inflammatory diseases. Hum Genet February 2012;131:21735170. doi:10.1007/s00439-0111057-y.

8. Bonin-Guillaume S, Zekry D, Giacobini E, Gold G, Michel J-P. [The economical impact of dementia]. Presse Med January 15, 2005;34:15685097.
9. Meek PD, McKeithan K, Schumock GT. Economic considerations in Alzheimer's disease. Pharmacotherapy April 1998;18:9543467.

10. Alzheimer's Association. 2013 Alzheimer's disease facts and figures. Alzheimers Dement March 2013;9:23507120. doi:10.1016/j. jalz.2013.02.003.

11. Mölsä PK, Marttila RJ, Rinne UK. Long-term survival and predictors of mortality in Alzheimer's disease and multi-infarct dementia. Acta Neurol Scand March 1995;91:7793228.

12.Zanetti O, Solerte SB, Cantoni F. Life expectancy in Alzheimer's disease (AD). Arch Gerontol Geriatr 2009;49 Suppl 1:19836639. doi:10.1016/j.archger.2009.09.035.

13. Alzheimer's Association. 2014 Alzheimer's disease facts and figures. Alzheimers Dement March 2014;10:24818261.

14. Blennow K, de Leon MJ, Zetterberg H. Alzheimer's disease. Lancet July 29, 2006;368:16876668. doi:10.1016/S0140-6736(06)69113-7.

15. Götz J, Ittner LM. Animal models of Alzheimer's disease and frontotemporal dementia. Nature Reviews Neuroscience July 2008;9. doi:10.1038/nrn2420.

16. Strittmatter WJ, Saunders AM, Schmechel D, Pericak-Vance M, Enghild J, Salvesen GS, et al. Apolipoprotein E: high-avidity binding to betaamyloid and increased frequency of type 4 allele in late-onset familial Alzheimer disease. Proc Natl Acad Sci U S A March 1, 1993;90:8446617.

17. Mahley RW, Weisgraber KH, Huang Y. Apolipoprotein E4: a causative factor and therapeutic target in neuropathology, including Alzheimer's disease. Proc Natl Acad Sci USA April 11, 2006;103:16567625. doi:10.1073/pnas.0600549103.

18. Petersen RC, Smith GE, Waring SC, Ivnik RJ, Kokmen E, Tangelos EG. Aging, Memory, and Mild Cognitive Impairment. International Psychogeriatrics December 1997;9. doi:10.1017/ S1041610297004717.

19. Eustache F, Rioux P, Desgranges B, Marchal G, Petit-Taboué MC, Dary $\mathrm{M}$, et al. Healthy aging, memory subsystems and regional cerebral oxygen consumption. Neuropsychologia July 1995;33:7477814.

20.Weinberger B, Herndler-Brandstetter D, Schwanninger A, Weiskopf D, Grubeck-Loebenstein B. Biology of Immune Responses to Vaccines in Elderly Persons. Clin Infect Dis April 1, 2008;46:18444828. doi:10.1086/529197.

21. Weiskopf D, Weinberger B, Grubeck-Loebenstein B. The aging of the immune system. Transplant International 2009;22. doi:10.1111/ j.1432-2277.2009.00927.x.

22. Sansoni P, Vescovini R, Fagnoni F, Biasini C, Zanni F, Zanlari L, et al. The immune system in extreme longevity. Exp Gerontol February 2008;43:17870272. doi:10.1016/j.exger.2007.06.008.

23. Shodell M, Siegal FP. Circulating, interferon-producing plasmacytoid dendritic cells decline during human ageing. Scand J Immunol November 2002;56:12410802.

24.Steger MM, Maczek C, Grubeck-Loebenstein B. Morphologically and functionally intact dendritic cells can be derived from the peripheral blood of aged individuals. Clin Exp Immunol September 1996;105:8809147.

25.Steger MM, Maczek C, Grubeck-Loebenstein B. Peripheral blood dendritic cells reinduce proliferation in in vitro aged $\mathrm{T}$ cell populations. Mech Ageing Dev February 1997;93:9089577.

26. Saurwein-Teissl M, Romani N, Grubeck-Loebenstein B. Dendritic cells 
in old age--neglected by gerontology? Mech Ageing Dev December 20, 2000;121:11164466.

27. Linton PJ, Dorshkind K. Age-related changes in lymphocyte development and function. Nat Immunol February 2004;5. doi:10.1038/ni1033.

28. Allman D, Miller JP. B cell development and receptor diversity during aging. Curr Opin Immunol October 2005;17:16054808. doi:10.1016/j. coi.2005.07.002.

29. Goronzy JJ, Weyand CM. T cell development and receptor diversity during aging. Curr Opin Immunol October 2005;17:16098723. doi:10.1016/j.coi.2005.07.020.

30. Weng N-P. Aging of the immune system: how much can the adaptive immune system adapt? Immunity May 2006;24:16713964. doi:10.1016/j.immuni.2006.05.001.

31.Itagaki S, McGeer PL, Akiyama H, Zhu S, Selkoe D. Relationship of microglia and astrocytes to amyloid deposits of Alzheimer disease. J Neuroimmunol October 1989;24:2808689.

32. Wyss-Coray T, Masliah E, Mallory M, McConlogue L, Johnson-Wood K, Lin C, et al. Amyloidogenic role of cytokine TGF-beta1 in transgenic mice and in Alzheimer's disease. Nature October 9, 1997;389:9335500. doi:10.1038/39321.

33. Lue LF, Walker DG, Rogers J. Modeling microglial activation in Alzheimer's disease with human postmortem microglial cultures. Neurobiol Aging December 2001;22:11755003.

34. Dantzer R, O'Connor JC, Freund GG, Johnson RW, Kelley KW. From inflammation to sickness and depression: when the immune system subjugates the brain. Nat Rev Neurosci January 2008;9:18073775. doi:10.1038/nrn2297.

35. Schenk D, Barbour R, Dunn W, Gordon G, Grajeda H, Guido T, et al. Immunization with amyloid-beta attenuates Alzheimer-disease-like pathology in the PDAPP mouse. Nature July 8, 1999;400:10408445. doi:10.1038/22124.

36. Dodart J-C, Bales KR, Gannon KS, Greene SJ, DeMattos RB, Mathis $C$, et al. Immunization reverses memory deficits without reducing brain Abeta burden in Alzheimer's disease model. Nat Neurosci May 2002;5:11941374. doi:10.1038/nn842.

37. Monsonego A, Zota V, Karni A, Krieger JI, Bar-Or A, Bitan G, et al. Increased $\mathrm{T}$ cell reactivity to amyloid beta protein in older humans and patients with Alzheimer disease. J Clin Invest August 2003;112:12897209. doi:10.1172/JCI18104.

38. Ethell DW, Shippy D, Cao C, Cracchiolo JR, Runfeldt M, Blake B, et al. Abeta-specific T-cells reverse cognitive decline and synaptic loss in Alzheimer's mice. Neurobiol Dis August 2006;23:16733088. doi:10.1016/j.nbd.2006.03.008.

39. Cao C, Arendash GW, Dickson A, Mamcarz MB, Lin X, Ethell DW. Abeta-specific Th2 cells provide cognitive and pathological benefits to Alzheimer's mice without infiltrating the CNS. Neurobiol Dis April 2009;34:19167499. doi:10.1016/j.nbd.2008.12.015.

40. Ghochikyan A, Mkrtichyan M, Petrushina I, Movsesyan N, Karapetyan A, Cribbs DH, et al. Prototype Alzheimer's disease epitope vaccine induced strong Th2-type anti-Abeta antibody response with Alum to Quil A adjuvant switch. Vaccine March 20, 2006;24:16368167. doi:10.1016/j.vaccine.2005.11.039.

41. Agadjanyan MG, Ghochikyan A, Petrushina I, Vasilevko V, Movsesyan $\mathrm{N}$, Mkrtichyan M, et al. Prototype Alzheimer's disease vaccine using the immunodominant B cell epitope from beta-amyloid and promiscuous T cell epitope pan HLA DR-binding peptide. J Immunol February 1, 2005;174:15661919.

42. Ghochikyan A, Mkrtichyan M, Petrushina I, Movsesyan N, Karapetyan A, Cribbs DH, et al. Prototype Alzheimer's disease epitope vaccine induced strong Th2-type anti-Abeta antibody response with Alum to Quil A adjuvant switch. Vaccine March 20, 2006;24:16368167. doi:10.1016/j.vaccine.2005.11.039.

43. Hock C, Konietzko U, Papassotiropoulos A, Wollmer A, Streffer J, von Rotz RC, et al. Generation of antibodies specific for beta-amyloid by vaccination of patients with Alzheimer disease. Nat Med November 2002;8:12379846. doi:10.1038/nm783.

44. Nicoll JAR, Wilkinson D, Holmes C, Steart P, Markham H, Weller RO. Neuropathology of human Alzheimer disease after immunization with amyloid-beta peptide: a case report. Nat Med April 2003;9:12640446. doi:10.1038/nm840.

45. Birmingham K, Frantz S. Set back to Alzheimer vaccine studies. Nat Med March 2002;8. doi:10.1038/nm0302-199b.

46. Robinson SR, Bishop GM, Lee H-G, Münch G. Lessons from the AN 1792 Alzheimer vaccine: lest we forget. Neurobiol Aging June 2004;25:15172738. doi:10.1016/j.neurobiolaging.2003.12.020.

47. Lemere CA, Beierschmitt A, Iglesias M, Spooner ET, Bloom JK, Leverone JF, et al. Alzheimer's disease abeta vaccine reduces central nervous system abeta levels in a non-human primate, the Caribbean vervet. Am J Pathol July 2004;165:15215183.

48.Zhang J, Wu X, Qin C, Qi J, Ma S, Zhang H, et al. A novel recombinant adeno-associated virus vaccine reduces behavioral impairment and beta-amyloid plaques in a mouse model of Alzheimer's disease. Neurobiol Dis December 2003;14:14678754.

49. Morgan D, Diamond DM, Gottschall PE, Ugen KE, Dickey C, Hardy J, et al. A beta peptide vaccination prevents memory loss in an animal model of Alzheimer's disease. Nature December 21, 2000;408:11140686. doi:10.1038/35050116.

50. Markesbery WR. Oxidative stress hypothesis in Alzheimer's disease. Free Radic Biol Med 1997;23:9165306.

51. Smith MA, Hirai K, Hsiao K, Pappolla MA, Harris PL, Siedlak SL, et al. Amyloid-beta deposition in Alzheimer transgenic mice is associated with oxidative stress. J Neurochem May 1998;70:9572310.

52. Jomova K, Vondrakova D, Lawson M, Valko M. Metals, oxidative stress and neurodegenerative disorders. Mol Cell Biochem December 2010;345:20730621. doi:10.1007/s11010-010-0563-x.

53. Axelsen PH, Komatsu H, Murray IVJ. Oxidative stress and cell membranes in the pathogenesis of Alzheimer's disease. Physiology (Bethesda) February 2011;26:21357903. doi:10.1152/ physiol.00024.2010.

54. Sultana R, Butterfield DA. Role of oxidative stress in the progression of Alzheimer's disease. J Alzheimers Dis 2010;19:20061649. doi:10.3233/JAD-2010-1222.

55. Ansari MA, Scheff SW. Oxidative stress in the progression of Alzheimer disease in the frontal cortex. J Neuropathol Exp Neurol February 2010;69:20084018. doi:10.1097/NEN.0b013e3181cb5af4.

56. Hiltunen M, van Groen T, Jolkkonen J. Functional roles of amyloidbeta protein precursor and amyloid-beta peptides: evidence from experimental studies. J Alzheimers Dis 2009;18:19584429. doi:10.3233/JAD-2009-1154.

57.Williams DR, Lees AJ. Progressive supranuclear palsy: 
clinicopathological concepts and diagnostic challenges. Lancet Neurol March 2009;8:19233037. doi:10.1016/S1474-4422(09)70042-0.

58. Roberts GW. Immunocytochemistry of neurofibrillary tangles in dementia pugilistica and Alzheimer's disease: evidence for common genesis. Lancet December 24, 1988;2:2904573.

59. Selkoe DJ, Podlisny MB. Deciphering the genetic basis of Alzheimer's disease. Annu Rev Genomics Hum Genet 2002;3:12142353. doi:10.1146/annurev.genom.3.022502.103022.

60. Hof PR, Perl DP, Loerzel AJ, Steele JC, Morrison JH. Amyotrophic lateral sclerosis and parkinsonism-dementia from Guam: differences in neurofibrillary tangle distribution and density in the hippocampal formation and neocortex. Brain Res July 4, 1994;650:7953661.

61. Radde R, Duma C, Goedert M, Jucker M. The value of incomplete mouse models of Alzheimer's disease. Eur J Nucl Med Mol Imaging March 2008;35 Suppl 1:18270700. doi:10.1007/s00259-007-0704-y.

62. Nalivaeva NN, Belyaev ND, Zhuravin IA, Turner AJ. The Alzheimer\&\#x27;s Amyloid-Degrading Peptidase, Neprilysin: Can We Control It? International Journal of Alzheimer's Disease July 26, 2012;2012. doi:10.1155/2012/383796.

63. Benilova I, Karran E, De Strooper B. The toxic A $\beta$ oligomer and Alzheimer's disease: an emperor in need of clothes. Nat Neurosci March 2012;15:22286176. doi:10.1038/nn.3028.

64. Walsh DM, Klyubin I, Fadeeva JV, Rowan MJ, Selkoe DJ. Amyloidbeta oligomers: their production, toxicity and therapeutic inhibition. Biochem Soc Trans August 2002;30:12196135. doi:10.1042/.

65. Mattson MP, Goodman Y. Different amyloidogenic peptides share a similar mechanism of neurotoxicity involving reactive oxygen species and calcium. Brain Res April 3, 1995;676:7796173.

66. Butterfield DA, Castegna A, Lauderback CM, Drake J. Evidence that amyloid beta-peptide-induced lipid peroxidation and its sequelae in Alzheimer's disease brain contribute to neuronal death. Neurobiol Aging October 2002;23:12392766.

67. Mark RJ, Hensley K, Butterfield DA, Mattson MP. Amyloid beta-peptide impairs ion-motive ATPase activities: evidence for a role in loss of neuronal $\mathrm{Ca} 2+$ homeostasis and cell death. J Neurosci September 1995;15:7666206.

68. Salminen A, Ojala J, Kauppinen A, Kaarniranta K, Suuronen T. Inflammation in Alzheimer's disease: Amyloid- $\beta$ oligomers trigger innate immunity defence via pattern recognition receptors. Progress in Neurobiology February 2009;87. doi:10.1016/j. pneurobio.2009.01.001.

69. D'Andrea MR, Cole GM, Ard MD. The microglial phagocytic role with specific plaque types in the Alzheimer disease brain. Neurobiol Aging June 2004;25:15172747. doi:10.1016/j.neurobiolaging.2003.12.026.

70.Wyss-Coray T, Loike JD, Brionne TC, Lu E, Anankov R, Yan F, et al. Adult mouse astrocytes degrade amyloid-beta in vitro and in situ. Nat Med April 2003;9:12612547. doi:10.1038/nm838.

71. Bard F, Cannon C, Barbour R, Burke RL, Games D, Grajeda H, et al. Peripherally administered antibodies against amyloid beta-peptide enter the central nervous system and reduce pathology in a mouse model of Alzheimer disease. Nat Med August 2000;6:10932230. doi:10.1038/78682.

72. Li M, Chen L, Lee DHS, Yu L-C, Zhang Y. The role of intracellular amyloid beta in Alzheimer's disease. Prog Neurobiol October 2007;83:17889422. doi:10.1016/j.pneurobio.2007.08.002.
73. Wu Z-C, Yu J-T, Li Y, Tan L. Clusterin in Alzheimer's disease. Adv Clin Chem 2012;56:22397031.

74.Yaqiong Li CS. Lipidated cyclic $\gamma$-AApeptides display both antimicrobial and anti-inflammatory activity. ACS Chemical Biology 2013. doi:10.1021/cb4006613.

75. Dragicevic N, Copes N, O’Neal-Moffitt G, Jin J, Buzzeo R, Mamcarz $\mathrm{M}$, et al. Melatonin treatment restores mitochondrial function in Alzheimer's mice: a mitochondrial protective role of melatonin membrane receptor signaling. J Pineal Res August 2011;51:21355879. doi:10.1111/j.1600-079X.2011.00864.x.

76. Dragicevic N, Delic V, Cao C, Copes N, Lin X, Mamcarz M, et al. Caffeine increases mitochondrial function and blocks melatonin signaling to mitochondria in Alzheimer's mice and cells. Neuropharmacology December 2012;63:22959965. doi:10.1016/j. neuropharm.2012.08.018.

77. Cao C, Cirrito JR, Lin X, Wang L, Wang L, Verges DK, et al. Caffeine suppresses amyloid-beta levels in plasma and brain of Alzheimer's disease transgenic mice. J Alzheimers Dis 2009;17:19581723. doi:10.3233/JAD-2009-1071.

78. Cao C, Wang L, Lin X, Mamcarz M, Zhang C, Bai G, et al. Caffeine synergizes with another coffee component to increase plasma GCSF: linkage to cognitive benefits in Alzheimer's mice. J Alzheimers Dis. 2011;25:21422521. doi:10.3233/JAD-2011-110110.

79. Cao C, Loewenstein DA, Lin X, Zhang C, Wang L, Duara R, et al. High Blood caffeine levels in MCI linked to lack of progression to dementia. J Alzheimers Dis 2012;30:22430531. doi:10.3233/JAD-2012-111781.

80. Cao C, Li Y, Liu H, Bai G, Mayl J, Lin X, et al. The potential therapeutic effects of THC on Alzheimer's disease. J Alzheimers Dis 2014;42:25024327. doi:10.3233/JAD-140093.

81. Ramírez-Rodríguez G, Vega-Rivera NM, Benítez-King G, Castro-García M, Ortíz-López L. Melatonin supplementation delays the decline of adult hippocampal neurogenesis during normal aging of mice. Neurosci Lett November 14, 2012;530:23043890. doi:10.1016/j. neulet.2012.09.045.

82. Morris MC, Evans DA, Bienias JL, Tangney CC, Bennett DA, Aggarwal $\mathrm{N}$, et al. Dietary intake of antioxidant nutrients and the risk of incident Alzheimer disease in a biracial community study. JAMA June 26, 2002;287:12076219.

83. Lahiri DK, Chen D, Ge Y-W, Bondy SC, Sharman EH. Dietary supplementation with melatonin reduces levels of amyloid beta-peptides in the murine cerebral cortex. J Pineal Res May 2004;36:15066046. doi:10.1111/j.1600-079X.2004.00121.x.

84. Wang C-M, Devries S, Camboni M, Glass M, Martin PT. Immunization with the SDPM1 peptide lowers amyloid plaque burden and improves cognitive function in the APPswePSEN1(A246E) transgenic mouse model of Alzheimer's disease. Neurobiol Dis September 2010;39:20493257. doi:10.1016/j.nbd.2010.05.013.

85. Janus C, Pearson J, McLaurin J, Mathews PM, Jiang Y, Schmidt SD, et al. A beta peptide immunization reduces behavioural impairment and plaques in a model of Alzheimer's disease. Nature December 21, 2000;408:11140685. doi:10.1038/35050110.

86. Schroer JA, Bender T, Feldmann RJ, Kim KJ. Mapping epitopes on the insulin molecule using monoclonal antibodies. Eur J Immunol September 1983;13:6193965. doi:10.1002/eji.1830130902.

87. Weiner HL, Lemere CA, Maron R, Spooner ET, Grenfell TJ, Mori C, et al. Nasal administration of amyloid-beta peptide decreases cerebral 
amyloid burden in a mouse model of Alzheimer's disease. Ann Neurol October 2000;48:11026440.

88. Lemere CA, Maron R, Spooner ET, Grenfell TJ, Mori C, Desai R, et al. Nasal A beta treatment induces anti-A beta antibody production and decreases cerebral amyloid burden in PD-APP mice. Ann N Y Acad Sci 2000;920:11193172.

89. Delamarre L, Mellman I. Harnessing dendritic cells for immunotherapy. Semin Immunol February 2011;23:21377379. doi:10.1016/j. smim.2011.02.001.

90. Gilchrest BA, Murphy GF, Soter NA. Effect of chronologic aging and ultraviolet irradiation on Langerhans cells in human epidermis. J Invest Dermatol August 1982;79:7097040.

91. Thiers BH, Maize JC, Spicer SS, Cantor AB. The Effect of Aging and Chronic Sun Exposure on Human Langerhans Cell Populations. J Investig Dermatol March 1984;82. doi:10.1111/1523-1747. ep12260055.

92. Villeda SA, Plambeck KE, Middeldorp J, Castellano JM, Mosher KI, Luo $\mathrm{J}$, et al. Young blood reverses age-related impairments in cognitive function and synaptic plasticity in mice. Nat Med June 2014;20. doi: $10.1038 / \mathrm{nm} .3569$.

93. Combs CK. Inflammation and microglia actions in Alzheimer's disease. J Neuroimmune Pharmacol December 2009;4:19669893. doi:10.1007/s11481-009-9165-3.

94. Szczepanik AM, Funes S, Petko W, Ringheim GE. IL-4, IL-10 and IL-13 modulate A beta(1--42)-induced cytokine and chemokine production in primary murine microglia and a human monocyte cell line. J Neuroimmunol February 1, 2001;113:11137576.

95. Larbi A, Pawelec G, Witkowski JM, Schipper HM, Derhovanessian E, Goldeck D, et al. Dramatic shifts in circulating CD4 but not CD8 T cell subsets in mild Alzheimer's disease. J Alzheimers Dis 2009;17:19494434. doi:10.3233/JAD-2009-1015.

96. Sastre M, Walter J, Gentleman SM. Interactions between APP secretases and inflammatory mediators. Journal of Neuroinflammation June 18 , 2008;5:18564425. doi:10.1186/1742-2094-5-25.

97. Sastre M, Dewachter I, Landreth GE, Willson TM, Klockgether T, van Leuven $F$, et al. Nonsteroidal anti-inflammatory drugs and peroxisome proliferator-activated receptor-gamma agonists modulate immunostimulated processing of amyloid precursor protein through regulation of beta-secretase. J Neurosci October 29, 2003;23:14586007.

98. Yamamoto M, Kiyota T, Horiba M, Buescher JL, Walsh SM, Gendelman $\mathrm{HE}$, et al. Interferon-gamma and tumor necrosis factor-alpha regulate amyloid-beta plaque deposition and beta-secretase expression in Swedish mutant APP transgenic mice. Am J Pathol February 2007;170:17255335. doi:10.2353/ajpath.2007.060378.

99. Bazoti FN, Tsarbopoulos A, Markides KE, Bergquist J. Study of the noncovalent interaction between amyloid-beta-peptide and melatonin using electrospray ionization mass spectrometry. J Mass Spectrom February 2005;40:15706607. doi:10.1002/jms.738.

100. Arendash GW, Schleif W, Rezai-Zadeh K, Jackson EK, Zacharia LC, Cracchiolo JR, et al. Caffeine protects Alzheimer's mice against cognitive impairment and reduces brain beta-amyloid production. Neuroscience November 3, 2006;142:16938404. doi:10.1016/j. neuroscience.2006.07.021.

101. Tolón RM, Núñez E, Pazos MR, Benito C, Castillo AI, Martínez-Orgado JA, et al. The activation of cannabinoid CB2 receptors stimulates in situ and in vitro beta-amyloid removal by human macrophages. Brain Res August 4, 2009;1283:19505450. doi:10.1016/j. brainres.2009.05.098.

102. Tanabe C, Ebina M, Asai M, Futai E, Sasagawa N, Katano K, et al. 1,3-Capryloyl-2-arachidonoyl glycerol activates alphasecretase activity and suppresses Abeta40 secretion in A172 cells. Neurosci Lett February 6, 2009;450:19041370. doi:10.1016/j. neulet.2008.11.039.

103. Meda L, Cassatella MA, Szendrei GI, Otvos L, Baron P, Villalba $\mathrm{M}$, et al. Activation of microglial cells by beta-amyloid protein and interferon-gamma. Nature April 13, 1995;374:7715705. doi:10.1038/374647a0.

104. Browne TC, McQuillan K, McManus RM, O’Reilly J-A, Mills KHG, Lynch MA. IFN- $\gamma$ Production by amyloid $\beta$-specific Th1 cells promotes microglial activation and increases plaque burden in a mouse model of Alzheimer's disease. J Immunol March 1, 2013;190:23365075. doi:10.4049/jimmunol.1200947.

105. Fillit H, Ding WH, Buee L, Kalman J, Altstiel L, Lawlor B, et al. Elevated circulating tumor necrosis factor levels in Alzheimer's disease. Neurosci Lett August 19, 1991;129:1745413.

106. Tobinick E, Gross H, Weinberger A, Cohen H. TNF-alpha modulation for treatment of Alzheimer's disease: a 6-month pilot study. MedGenMed 2006;8:16926764.

107. Sheng JG, Ito K, Skinner RD, Mrak RE, Rovnaghi CR, Van Eldik LJ, et al. In vivo and in vitro evidence supporting a role for the inflammatory cytokine interleukin-1 as a driving force in Alzheimer pathogenesis. Neurobiol Aging October 1996;17:8892349.

108. Ben-Menachem-Zidon O, Ben-Menahem Y, Ben-Hur T, Yirmiya R. Intra-hippocampal transplantation of neural precursor cells with transgenic over-expression of IL-1 receptor antagonist rescues memory and neurogenesis impairments in an Alzheimer's disease model. Neuropsychopharmacology January 2014;39:23954849. doi:10.1038/npp.2013.208.

109. Gambi F, Reale M, Iarlori C, Salone A, Toma L, Paladini C, et al. Alzheimer patients treated with an AchE inhibitor show higher IL-4 and lower IL-1 beta levels and expression in peripheral blood mononuclear cells. J Clin Psychopharmacol June 2004;24:15118486.

110. Bauer J, Strauss S, Volk B, Berger M. IL-6-mediated events in Alzheimer's disease pathology. Immunol Today November 1991;12:1786076. doi:10.1016/0167-5699(91)90148-M.

111. Sanjabi S, Zenewicz LA, Kamanaka M, Flavell RA. Anti-inflammatory and pro-inflammatory roles of TGF-beta, IL-10, and IL-22 in immunity and autoimmunity. Curr Opin Pharmacol August 2009;9:19481975. doi:10.1016/j.coph.2009.04.008.

112. Di Bona D, Rizzo C, Bonaventura G, Candore G, Caruso C. Association between interleukin-10 polymorphisms and Alzheimer's disease: a systematic review and meta-analysis. J Alzheimers Dis 2012;29:22356904. doi:10.3233/JAD-2012-111838.

113. Vom Berg J, Prokop S, Miller KR, Obst J, Kälin RE, Lopategui-Cabezas I, et al. Inhibition of IL-12/IL-23 signaling reduces Alzheimer's disease-like pathology and cognitive decline. Nat Med December 2012;18:23178247. doi:10.1038/nm.2965.

114. Laske C, Stellos K, Stransky E, Leyhe T, Gawaz M. Decreased plasma levels of granulocyte-colony stimulating factor (G-CSF) in patients with early Alzheimer's disease. J Alzheimers Dis 2009;17:19494436. doi:10.3233/JAD-2009-1017.

115. Tsai K-J, Tsai Y-C, Shen C-KJ. G-CSF rescues the memory impairment 
of animal models of Alzheimer's disease. J Exp Med June 11, 2007;204:17517969. doi:10.1084/jem.20062481.

116. Butovsky O, Kunis G, Koronyo-Hamaoui M, Schwartz M. Selective ablation of bone marrow-derived dendritic cells increases amyloid plaques in a mouse Alzheimer's disease model. Eur J Neurosci July 2007;26:17623022. doi:10.1111/j.1460-9568.2007.05652.x.

117. Luo Z, Li J, Nabar NR, Lin X, Bai G, Cai J, et al. Efficacy of a therapeutic vaccine using mutated $\beta$-amyloid sensitized dendritic cells in Alzheimer's mice. J Neuroimmune Pharmacol September 2012;7:22684353. doi:10.1007/s11481-012-9371-2.

118. Lopez OL, Becker JT, Wisniewski S, Saxton J, Kaufer DI, DeKosky ST. Cholinesterase inhibitor treatment alters the natural history of Alzheimer's disease. J Neurol Neurosurg Psychiatr March 2002;72:11861686.

119. Reisberg B, Doody R, Stöffler A, Schmitt F, Ferris S, Möbius HJ. Memantine in Moderate-to-Severe Alzheimer's Disease. New England Journal of Medicine April 3, 2003;348:12672860. doi:10.1056/NEJMoa013128.

120. Rosales-Corral SA, Acuña-Castroviejo D, Coto-Montes A, Boga JA, Manchester LC, Fuentes-Broto L, et al. Alzheimer's disease: pathological mechanisms and the beneficial role of melatonin. Journal of Pineal Research 2012;52. doi:10.1111/j.1600079X.2011.00937.x.

121. Matsubara E, Bryant-Thomas T, Pacheco Quinto J, Henry TL, Poeggeler B, Herbert D, et al. Melatonin increases survival and inhibits oxidative and amyloid pathology in a transgenic model of Alzheimer's disease. J Neurochem June 2003;85:12753069.

122. Cardinali DP, Brusco LI, Liberczuk C, Furio AM. The use of melatonin in Alzheimer's disease. Neuro Endocrinol Lett April 2002;23 Suppl 1:12019347.

123. Arendash GW, Mori T, Cao C, Mamcarz M, Runfeldt M, Dickson A et al. Caffeine reverses cognitive impairment and decreases brain amyloid-beta levels in aged Alzheimer's disease mice. J Alzheimers Dis 2009;17:19581722. doi:10.3233/JAD-2009-1087.

124. Christen Y. Oxidative stress and Alzheimer disease. Am J Clin Nutr February 2000;71:10681270.

125. Lim GP, Yang F, Chu T, Chen P, Beech W, Teter B, et al. Ibuprofen suppresses plaque pathology and inflammation in a mouse model for Alzheimer's disease. J Neurosci August 1, 2000;20:10908610. 